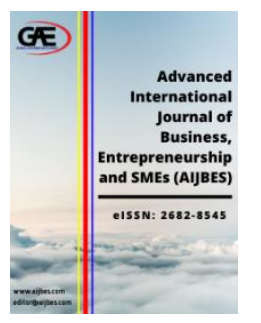

\author{
ADVANCED INTERNATIONAL JOURNAL OF \\ BUSINESS, ENTREPRENEURSHIP AND SMES \\ (AIJBES) \\ www.aijbes.com
}

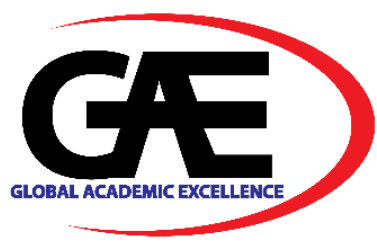

\title{
COMPARATIVE ANALYSIS OF THE EFFICIENCY OF ISLAMIC BANKING IN INDONESIA BEFORE AND DURING COVID-19 PANDEMIC
}

\author{
Safira Khoirunnisa ${ }^{1 *}$, Arson Aliludin $^{2}$ \\ 1 School of Business and Management, Bandung Institute of Technology, Indonesia \\ Email: safira_khoirunnisa@sbm-itb.ac.id \\ 2 School of Business and Management, Bandung Institute of Technology, Indonesia \\ Email: arson@sbm-itb.ac.id \\ Corresponding Author
}

\section{Article Info:}

Article history:

Received date: 27.07 .2021

Revised date: 15.08 .2021

Accepted date: 29.08.2021

Published date: 09.09.2021

\section{To cite this document:}

Khoirunnisa, S., \& Aliludin, A. (2021). Comparative Analysis Of The Efficiency Of Islamic Banking In Indonesia Before And During Covid-19 Pandemic. Advanced International Journal of Business, Entrepreneurship and SMEs, 3 (9), 277-287.

DOI: $10.35631 /$ AIJBES.39019.

This work is licensed under $\mathrm{CC}$ BY 4.0

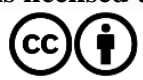

\begin{abstract}
:
In 2019, COVID-19 starts to become a global emergence and keeps spreading all over the world. It has begun to enter Indonesia in February 2020 and has developed the social restriction and lockdown policy that leads to the decline in the economy. In contrast, the Islamic banking industry has escalated marginally in the past century. As a business entity, Islamic Banking has to maintain its business performance, one of which is by measuring the efficiency of the bank. The aim of this study is to analyse whether the Islamic Banking industry is disrupted by the occurrence of the COVID-19 pandemic, by measuring the efficiency of Islamic Banking. This study uses the Data Envelopment Analysis method with Variable Return to Scale model in output orientation. The variables used are based on the Intermediation approach which are Third Party Funds with Total Assets for the input, and Financing with Operating Income for the output. The samples are from all of the Islamic Banks in Indonesia in 2019-2021 except PT Bank Net Indonesia Syariah (total of 13). After calculating the efficiency, to see whether there is a difference between the Islamic Banks' efficiency before and during the COVID-19 pandemic, the Kolmogorov-Smirnov and MannWhitney U Test are used. The result of this study is that the Islamic banks in Indonesia have not been efficient both before and during the COVID-19 Pandemic, with a score of $68,12 \%$ for before and $69,64 \%$ for during pandemic. Moreover, the correlation analysis using the Mann-Whitney U test result indicates that the efficiency score before and during the COVID19 pandemic has no significant difference. Hence, this illustrates that the occurrence of the COVID-19 pandemic didn't affect the Islamic Banking industry in Indonesia, particularly on their efficiency.
\end{abstract}




\section{Introduction}

At the end of the year of 2019, the world starts to experience an emergence and global disease from a virus named coronavirus. The coronavirus or mainly known as COVID-19 was beginning to appear during December 2019 in Wuhan, at the animal and seafood market which is one of the emerging business hubs in China (Sukur et al., 2020). COVID-19 is one of the family of viruses that could cause disease in animals such as bats, snakes, camels, etc, and recently began to evolve and infect humans as well. In humans, COVID-19 causes the infection in the respiratory system starting from the common cold to the more severe disease which is identical to the Middle East Respiratory Syndrome (MERS) and Severe Acute Respiratory Syndrome (SARS). This COVID-19 spreads through a person's saliva (could be cough or sneeze), direct contact with an infected person, and by touching the face including eyes, nose, or mouth with a dirty hand that might have been appeared with the virus, therefore it resulted in the rapid spread of the virus throughout the world (Sukur et al., 2020).

The first case of coronavirus disease in Indonesia was announced by the government on March 2nd, 2020. Those first cases were carried out by 2 Indonesian citizens who were having direct contact with Japanese citizen that was visiting Indonesia (Sukur et al., 2020). However, BNPB has already issued Decree of the Head of BNPB Number 9.A Year 2020 concerning the Determination of Certain Emergency Status of Disease Outbreaks due to Corona Virus in Indonesia in the early 2020, which is valid for 32 days from January 28 - February 28, 2020 (Wibowo, 2020). Until March 11th, 2020, the first death case from coronavirus disease occurred in Solo, Central Java to a 59 years old man after attending a seminar in Bogor in February (Sukur et al., 2020). And then the number of patients infected with the COVID-19 virus keeps increasing day by day and has spread across 34 provinces. Therefore, in order to prevent the spread of the virus throughout the society, strategies have been developed by Indonesian government by implementing Social Distancing to minimize the direct contact of the society to prevent people with illness from making direct contact with other people who are healthy (Sukur et al., 2020). Moreover, the government also adopted strict social restriction policies which encourage staying at home or mainly known as lockdown (Nugroho et al., 2020). The implementation of the lockdown includes several things, namely the closure of school and work places, restrictions on religious activities, restrictions on activities in public facilities, and others (Sukur et al., 2020).

Nevertheless, the social restriction, lockdown policies, and a number of public policies that have been implemented to limit the mobility of citizens has also caused a decline of the economy in the countries (Nugroho et al., 2020). The decline occurred due to the economic activities that have been slowed down because the public could not hold the business activities with the regular normal condition. Indonesia, as one of the countries that are also exposed to COVID-19, also experiences the effect of the COVID-19 pandemic. The economic crisis caused by COVID-19 pandemic will also influence the financial sector. It could occur in the form of pressure on the inflation rate, disruption to the supply chain due to reduced imports of raw materials from affected countries, the potential for rising balance of payments, undermined consumer confidence, upsurge of unemployment, and low foreign investment (Otoritas Jasa Keuangan, 2020). Moreover, in Banking Industry, there is an impact on the financial flow Copyright (C) GLOBAL ACADEMIC EXCELLENCE (M) SDN BHD - All rights reserved 
disruptions since the creditors are not being able to pay their debt. This occurs because the creditors are not being paid due to the business closure, the employees are also not fully paid or even lead to unemployment which reduces the purchasing power of the community. In addition, the closure of the stores, jobs, and services affected the income of the employees and lead to the the layoffs (Nugroho et al., 2020).

On the other hand, in the past few years the Islamic banking industry has escalated marginally (Islamic Financial Services Board, 2020). Based on Otoritas Jasa Keuangan, the growth of Islamic Banking in Indonesia is illustrated in the ratio, where the Capital Adequacy Ratio of total Islamic Banks are increasing over the year, which indicates that the Islamic Banks have the ability in enduring the probability risk of the bank. The Return on Assets and Net Operating Margin is also rising, which respectively illustrates that the Islamic Banks ability to obtain the profits from the assets used, and the profit from business operations as a percentage of revenue are also escalated over the year. Moreover, the Operating Expenses to Operating Revenue Ratio, Non-Performing Financing, and Financing to Deposit Ratio are decreasing, which respectively states that the Islamic bank ability to control the expense are increasing, the Islamic bank's competence in minimizing the financing problems are increasing, and that the Islamic bank's capability in liquidity are increasing.

As a business entity, the Banking Industry including the Islamic Banking have to maintain their business performances. One way to measure the performance of the Islamic Banking is by calculating the efficiency score. The efficiency could give an illustration about the performance of the Islamic Banking. A bank that is considered as efficient could indicate that their performance is good, and the banks that are not efficient could be considered to have a weak performance. With a good performance reputation, a bank could convince the investors that the money that is invested will give profits, could give the customers the convenience to transact with less charge, and could give benefits to the government in the form of taxes (Hidayat, 2014). Therefore, this study aims to investigate whether the COVID-19 pandemic has the impact on the efficiency of Islamic Banking in Indonesia.

\section{Literature Review}

\section{Islamic Banking}

According to Otoritas Jasa Keuangan in 2019, banking system in Indonesia is undergoing a dual banking system mechanism, which are Conventional Banks (CB) and Islamic Banks (IB). The Conventional Bank is a bank that conducts their business activities based on conventional principles and based on the regular type of banks. On the other hand, Islamic Bank is the bank that is conducting their business activities based on sharia principles, which is the Islamic law principles based on fatwa (legal decisions) issued by an institution that has the authority. Furthermore, those banking are also divided into two, namely the Commercial Banks, they provide services related to payment flows, which includes Conventional Commercial Banks (CCB) and Islamic Commercial Banks (ICB), and also Rural Banks that do not provide services related to payment flows, that includes Rural Banks (RB) and Islamic Rural Banks (IRB). As of February 2021, there are 121 commercial banks in Indonesia, consisting of 107 conventional commercial banks and 14 sharia commercial banks (Sugiharto et al., 2021).

Sharia banks or mainly known as Islamic banks are banks that carry out business activities based on Sharia principles, which is the rules of agreements based on Islamic law between banks and other parties for depositing funds and/or financing business activities, or other 


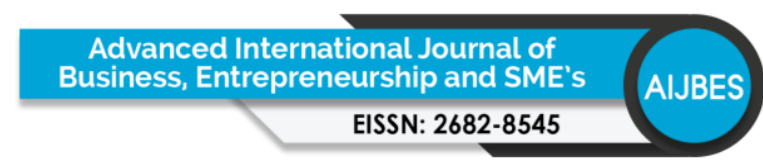

Volume 3 Issue 9 (September 2021) PP. 277-287

DOI 10.35631/AIJBES.39019

activities declared in accordance with Sharia principles (Ascarya and Yumanita, 2005). Islamic banks are different from conventional banks in general, where the main difference lies in the operating base used. Conventional banks operate based on the interest, while Islamic banks operate on the basis of profit sharing, buying and selling, and leasing. This difference is based on the beliefs that interest contains an element of usury which is prohibited by Islam. According to the Islamic view, in the interest system there is an element of injustice, since the owner of the fund requires the borrower to pay more than what was borrowed, regardless of whether the borrower makes a profit or even experiences a loss. In contrast, the profit sharing system used by Islamic banks is a system where borrowers and lenders distribute the risks and profits by sharing according to the agreement, therefore neither party is harmed by the other party (Ascarya and Yumanita, 2005).

\section{Banking Efficiency}

Based on Riani and Hendrawan (2020), Efficiency is the result of comparing input/input with output/output, meaning how much output is produced from the input used. A company can be considered efficient if with the same output it can use smaller inputs compared to other companies or can produce larger amounts of output using the same input.

While according to Muharam and Pusvitasari (2007), Efficiency in banking is also a benchmark in measuring bank performance where efficiency is the answer to difficulties in calculating performance measures such as the level of allocation, technical and total efficiency. The allocative efficiency or mainly known as economic efficiency is where the economic unit to operate at the level of the marginal value of the product equals the marginal cost. Where technical efficiency is a combination of capacity and the ability of an economic unit to produce up to a maximum level of output from a number of inputs and technology. Meanwhile, total efficiency is the sum of the allocation efficiency and technical efficiency.

\section{Methodology}

\section{Operations Variable}

Variables used in this research are formulated from the intermediation approach to define the correlation between input and output in financial institutions. This approach is considering the financial institution as an intermediator, which converts and transfers financial assets from the excessed parties to deficit parties (Indrawati, 2009). In addition, this intermediation approach takes a view of the financial institutions primary function which is the loans generator (Muharam \& Pusvitasari, 2007). From the bank's function as an intermediary, there are several inputs such as savings, operating cost, fixed assets, capital, and so on which will be converted into output that will maximize the efficiency value of the bank, such as financing, operating income, cash, investment, etc. Therefore, from various inputs and outputs, this research used 4 variables which contain 2 input variables and 2 output variables. The input variables chosen are Third Party Funds and Assets while the output variables are Financing and Operating Income, as follows:

\section{Third Party Funds (Input Variable 1: X1)}

Third Party Funds is the amount of money that is generated from the customers in the form of deposits collected by the bank which then offered by the bank in various forms for the customers according to each bank, where these deposits furthermore become the source of funding for other parties who need funds. This variable is chosen by the consideration since the Third-Party Fund is an element of the formation of income of the bank from customers 
which is channelled in the form of financing. The data of Third-Party Funds could be derived from the balance sheet of the Wadiah Savings Fund.

\section{Total Assets (Input Variable 2: X2)}

Assets are wealth or profits owned by a bank that are obtained as a result of a past transaction or event. Assets can be used to assist the operation of a bank. Asset value is known from the bank's financial statements from its balance sheet in the form of total assets. This variable is chosen by the consideration of, from the assets owned, the bank can operate as optimally as possible with the existing bank asset. The data of Assets could be derived from the balance sheet of the Total Assets.

\section{Financing (Output Variable 1: Y1)}

Financing is a distribution of funds for parties who need funds. Financing becomes the choice of output variables due to the distribution of financing funds as the main activity of banks in banking business activities to seek profit. The amount of financing can be seen in the financial statements. This variable is chosen since financing is the distribution of funds to finance economic and business activities that generate added value through the process of delivering services, trade, and production, which then will increase the profit of the banks. The data of the Financing could be derived from the balance sheet of the Profit Sharing and Lease Financing.

Operating Income (Output Variable 2: Y2)

Operating income is the obtained revenue by the bank generated from the main activity as an intermediary between the owner of funds and those who need funds. In the financial statements, it occurs in a profit / loss statement. This variable is chosen since operating income could be indicated as the outcome of the banking's operations. The data of the Operating Income could be derived from the income statement of the Operating Income and Expenses from Disbursement of Funds and other than Disbursement of Funds.

\section{Hypotheses Development}

Islamic Banks in Indonesia are generally growing over the past few years. However, the COVID-19 pandemic appeared and affecting the economic growth of the country and is projected to affect the banking industry as well. Measuring the efficiency could give an illustration of how a particular bank are performed. Hence, to see whether the COVID-19 has an impact to Islamic Banking in Indonesia, the hypotheses are developed as follows:

$\mathrm{H} 0: \mathrm{e}_{\mathrm{ij}}=\mathrm{e}_{\mathrm{ij}}{ }^{1}$, which illustrates that there is no difference of the Islamic Bank's efficiency before and during COVID-19 pandemic

$\mathrm{H} 1: \mathrm{e}_{\mathrm{ij}} \neq \mathrm{e}_{\mathrm{ij}}{ }^{1}$, which illustrates that there is a difference of the Islamic Bank's efficiency before and during COVID-19 pandemic.

\section{Data Source and Collection Method}

This research uses a quantitative analysis method with secondary data in numerical as a resource. The data are obtained from each Islamic Banks Monthly Reports that are published in the Otoritas Jasa Keuangan's website, on the link: www.ojk.go.id, which are Total Assets, Third Party Funds, Financing, and Operating Income from the balance sheet and the income statement. The information that is used in this research is starting from February 2019 to January 2020. Where February 2019 to January 2020 indicates the situation before COVID-19 pandemic, and February 2020 until January 2022 represent the condition during COVID-19 pandemic, thus the difference could be comprehended. The population of this research is PT Copyright (C) GLOBAL ACADEMIC EXCELLENCE (M) SDN BHD - All rights reserved 
Bank Aceh Syariah (BASY), PT BPD Nusa Tenggara Barat Syariah (NTBS), PT Bank Muamalat Indonesia (BMUI), PT Bank Victoria Syariah (BVSY), PT Bank BRI Syariah (BRIS), PT Bank Jabar Banten Syariah (BJBS), PT Bank BNI Syariah (BNIS), PT Bank Syariah Mandiri (BSMR), PT Bank Mega Syariah (BMGS), PT Bank Panin Dubai Syariah (BPDS), PT Bank Syariah Bukopin (BSYB), PT BCA Syariah (BCAS), and PT Bank Tabungan Pensiunan Nasional Syariah (BTPN). While PT. Bank Net Indonesia Syariah is not included because they apparently did not conduct the financing activities.

\section{Data Analysis Method}

In order to reach the objective of this research several methods are used to analyze the hypotheses that has been developed. The methods are firstly the efficiency measurement that further will be tested in several statistics method to prove the hypotheses.

\section{Data Envelopment Analysis}

To generate the analysis of the efficiency, this research uses the Data Envelopment Analysis (DEA) technique. DEA is a non-parametric method that uses linear programming techniques as a base. The DEA calculates a scalar measure of efficiency and determines the efficient input and output levels for the unit evaluated.

In addition, the analysis used is the assumption of Variable Return to Scale (VRS) with the output-oriented. The VRS is used due to the reality that not all DMU (which in this case is banks) operate at optimal scale. Moreover, the output orientation is used in this study since it is assumed that the banking industry in Indonesia is very competitive, this is indicated by the large number of commercial banks in Indonesia. However, all models of the orientation will estimate the same frontier at the end. The difference between the input and output orientations of the DEA model only lies in the size used of input and output in determining efficiency.

This research also uses the intermediation approach since it is related to the function of banks as intermediary institutions where various inputs are owned by banks such as deposits, fixed assets, etc. that will be converted into output that will maximize the efficiency value of the bank concerned, such as in the form of credit (financing), operating income, etc.

$$
\begin{aligned}
& \text { Objective function: } \\
& \text { Constraint to: } \\
& \begin{array}{ll}
\varepsilon_{s} y_{i s}-\sum_{r=1}^{n} \phi_{r} y_{i r} \geq 0 & i=1,2, \ldots, m ; \\
\sum_{r=1}^{n} \phi_{r} x_{i r} \geq x_{i s} & j=1,2, \ldots, n ; \\
\phi_{r} \geq 0 & \\
0 \leq \varepsilon_{s} \leq 1 &
\end{array}
\end{aligned}
$$

Where: $\varepsilon_{\mathrm{s}}=$ Efficiency of DMU searched.

$\phi_{r}=$ Weight (changing variables).

$y_{i r}=$ Output Variables.

$x_{i r}=$ Input Variables. 
Kolmogorov-Smirnov

The Kolmogorov-Smirnov Test is a data normality testing technique, to see whether a data distribution is in accordance with a normal distribution or not.

$$
\mathrm{D}=\text { Maximum }|\mathrm{FT}-\mathrm{FS}|
$$

Where: $\mathrm{D}=$ Value of Kolmogorov-Smirnov Test

FT = Normal Cumulative Probability

FS = Empirical Cumulative Probability

In testing the significance, the largest |FT - FS | value will be compared to the value of the Kolmogorov Smirnov table in the table of Quantile Statistics Kolmogorov Values Normal Distribution. If the the largest |FT - FS | value is less than or equal to the Kolmogorov Smirnov table value, then the data are normally distributed. If the value |FT - FS | is greater than the value of Kolmogorov Smirnov's table, then the data are not normally distributed.

\section{Independent Sample T-Test}

Independent Sample T-Test is a method used to compare two groups of means from two different samples (independent). In principle, the Independent Sample T-Test functions to determine whether there is a difference in the mean between 2 populations by comparing the two samples means.

$$
t_{\text {count }}=\frac{M_{1}-M_{2}}{\sqrt{\frac{S S_{1}+S S_{2}}{n_{1}+n_{2}-2}\left(\frac{1}{n_{1}}+\frac{1}{n_{2}}\right)}}
$$

Where: $\mathrm{M}_{1}=$ group mean score 1

$\mathrm{M}_{2}=$ group mean score 2

$\mathrm{SS}_{1}=$ sum of square group 1

$\mathrm{SS}_{2}=$ sum of square group 2

$\mathrm{n}_{1}=$ number of subjects/sample group 1

$\mathrm{n}_{2}=$ number of subjects/samples group 2

\section{Mann Whitney-U Test}

The Mann-Whitney U Test is a non-parametric statistical test that is used on ordinal or interval data, if the data does not meet one or more hypothesis prerequisite tests. Similar to the t-test, the Mann-Whitney U Test can also be used to analyze whether there is a difference between the means of two independent data.

Where: $\mathrm{U}=$ Mann Whitney Value

$$
U=N_{1} N_{2}+\frac{N_{1}\left(N_{1}+1\right)}{2}-R
$$

$\mathrm{N}_{1}=$ Number of first samples

$\mathrm{N}_{2}=$ Number of second samples

$\mathrm{R}=$ Number of sample levels

\section{Discussions and Analysis}

The result of the efficiency analysis with Data Envelopment Analysis VRS model in the period of before COVID-19 pandemic, shows that the Islamic Banking efficiency score of banks that is efficient (efficiency score of 100\%) in Indonesia, is only amounted to 6 periods. 
Table 1: Efficiency of each Islamic Banks Before COVID-19 Period

Months

\begin{tabular}{|c|c|c|c|c|c|c|c|c|c|c|c|c|c|}
\hline \multirow{2}{*}{ No. } & \multirow{2}{*}{ Banks } & \\
\hline & & Feb19 & Iar19 & Apr19 & May19 & Jun19 & Jul19 & Aug19 & Sep19 & Oct19 & Nov19 & Dec19 & Jan20 \\
\hline 1. & BASY & 0,171 & 0,214 & 0,256 & 0,313 & ,315 & 0,375 & 0,438 & 0498 & 0.500 & 0,553 & 0,608 & 0,113 \\
\hline 2. & NTBS & 0 & 55 & 302 & 42 & 82 & 77 & 488 & 12 & 78 & 537 & 702 & ,421 \\
\hline 3. & BMUI & 0,954 & 0,949 & 0,930 & 16 & 02 & 0,876 & 0,890 & 0,898 & 0,892 & 0,947 & 951 & 0,910 \\
\hline 4. & BVSY & 0,872 & 1,000 & 0 & & & 0,831 & 0,741 & 0,737 & 0,751 & 0,796 & 41 & 000 \\
\hline 5. & BRIS & 0,717 & 0,764 & 0,762 & 0,781 & 321 & 0,851 & 0,867 & 0,910 & 0,938 & 0,998 & 0,948 & 0,888 \\
\hline 6. & BJBS & 0,261 & 301 & 0,333 & 367 & 97 & 0,433 & 0,438 & 0,460 & 0,482 & 0,485 & 539 & 0,283 \\
\hline 7. & BNIS & 0,622 & 0,633 & 0,683 & 0,707 & 45 & 0,739 & 0,706 & 0,761 & 0,800 & 0,828 & 812 & 0,679 \\
\hline 8. & BSMR & 0,912 & 0,978 & 0,974 & 0,994 & 0,990 & 0,980 & 0,976 & 1,000 & 0,974 & 0,995 & 1,000 & 0,953 \\
\hline 9. & BMGS & 0,287 & 0,348 & 0,404 & 0,499 & 0,539 & 0,599 & 0,674 & 0,738 & 0,804 & 0,872 & 0,917 & 0,329 \\
\hline 10. & BPDS & 0,886 & 0,938 & 0,963 & 0,939 & 0,938 & 0,934 & 0,953 & 0,965 & 0,969 & 0,963 & 0,944 & 0,943 \\
\hline 11. & BSYB & 0,540 & 0,521 & 0,532 & 0,525 & 0,531 & 0,576 & 0,578 & 0,634 & 0,650 & 0,685 & 0,727 & 0,579 \\
\hline 12. & BCAS & 0,555 & 0,587 & 0,617 & 0,638 & 0,632 & 0,651 & 0,609 & 0,616 & 0,627 & 0,669 & 0,716 & 0,609 \\
\hline 13. & BTPNS & 0,180 & 0,273 & 0,361 & 0,436 & 0,512 & 0,600 & 0,682 & 0,767 & 0,836 & 0,914 & 1,000 & 0,094 \\
\hline & & $\mathbf{0 , 5 5 0}$ & 0,597 & $\mathbf{0 , 6 1 8}$ & 0,658 & 0,674 & 0,694 & 0,695 & $\mathbf{0 , 7 3 0}$ & 0,746 & $\mathbf{0 , 7 8 8}$ & $\mathbf{0 , 8 2 3}$ & $\mathbf{0 , 6 0 0}$ \\
\hline
\end{tabular}

Source: Processed data with DEAP-xp 2.1

That efficient periods appeared in 3 banks which is PT Bank Victoria Syariah (3 months), PT Bank Syariah Mandiri (2 months), and PT Bank Tabungan Pensiun Nasional Syariah (1 month) in before COVID-19 pandemic. While during COVID-19 pandemic period, the result of the efficiency analysis with Data Envelopment Analysis VRS, shows that the Islamic Banking efficiency score that is efficient (efficiency score of 100\%) in Indonesia, is increasing which amounted to 13 period, that appeared in 5 banks which is PT Bank Victoria Syariah (1 month), PT Bank BRI Syariah (1 month), PT Bank Syariah Mandiri (5 months), PT Bank Panin Dubai Syariah (3 months) and PT Bank Syariah Bukopin (3 month) in during COVID-19 pandemic.

Table 2: Efficiency of Each Islamic Banks after COVID-19 Period

\section{Months}

No. Banks

Feb20 Mar20 Apr20

May20

Jun20 Jul20 Aug20

Sep20

Oct20 Nov20

Dec20 Jan21

.

3

4

\section{5.}

6.

8

1

11

11.

1

$\begin{array}{lll}\text { BASY } & 0,139 \\ \text { NTBS } & 0,422\end{array}$

0,173

0,214

0,246

$0,266 \quad 0,306$

0,304

0,340

0,364

0,411

0,456

0,134

0,408

0,417

0,445

0,467

0,551

0,551

0,525

0,583

0,594

0,694

0,495

.

0,911

0,911

0,912

0,938

0,952

0,950

0,940

0,931

0,922

0,927

0,904

. BRIS

0,912

0,996

0,981

0,779

$0,778 \quad 0,870$
0,967

0,941

0,933

0,991

1,000

0,767

0,530

BJBS

0,277

0,309

0,330

1,000

0,967

0,982

0,954

0,908

0,890

0,898

0,903

0,854

BNIS

0,649

0,659

0,651

0,649

$0,389 \quad 0,411$

0,441

0,441

0,470

0,495

0,477

0,271

. BSMR

0,932

0,980

0,975

0,994

$1,000 \quad 1,000$

0,644

0,655

0,678

0,716

0,742

0,610

9. BMGS

$\begin{array}{lll}0,374 & 0,444\end{array}$

0,487

0,552

$0,617 \quad 0,672$

0,994

0,987

0,988

1,000

1,000

1,000

0. BPDS

0,914

0,937

0,923

0,963

$0,967 \quad 0,956$

0,697

0,740

0,647

0,706

0,723

0,245

11. BSYB 0,584

0,700

0,717

0,773

$0,857 \quad 0,916$

0,959

0,975

1,000

0,991

1,000

1,000

12.

0,602

0,633

0,676

$0,666 \quad 0,661$

0,652

0,941

1,000

1,000

1,000

0,970

0,681

0,728

0,694

0,657

0,556 
Volume 3 Issue 9 (September 2021) PP. 277-287 DOI 10.35631/AIJBES.39019

\begin{tabular}{|c|c|c|c|c|c|c|c|c|c|c|c|c|}
\hline 13. BTPNS & 0,180 & 0,265 & 0,304 & 0,372 & 0,439 & 0,518 & 0,597 & 0,676 & 0,739 & 0,818 & 0,902 & 0,083 \\
\hline Mean & 0,584 & 0,625 & 0,638 & 0,670 & 0,690 & 0,726 & 0,740 & 0,749 & 0,770 & $\mathbf{0 , 7 8 8}$ & 0,788 & 0,589 \\
\hline
\end{tabular}

After calculating the efficiency score of Islamic banks, to see whether the growth of the Islamic banks is disrupted by COVID-19 pandemic or not, the difference test must be carried out to test the hypotheses if there is any difference of the efficiency score of Islamic banks before and during COVID-19 pandemic. Before carrying out a difference test of the efficiency between before and during COVID-19 pandemic, a normality test is carried out first to determine which different test analysis tools to be used. The normality test is conducted using the Kolmogorov Smirnov test with the SPSS software, the result can be seen in Figure 1 as follows.

\begin{tabular}{|c|c|c|}
\hline \multicolumn{3}{|c|}{ One-Sample Kolmogorov-Smirnov Test } \\
\hline & & VAR00002 \\
\hline N & & 312 \\
\hline \multirow[t]{2}{*}{ Normal Parameters ${ }^{a, b}$} & Mean & 68880 \\
\hline & Std. Deviation & .246583 \\
\hline \multirow[t]{3}{*}{ Most Extreme Differences } & Absolute & .131 \\
\hline & Positive & .103 \\
\hline & Negative & -.131 \\
\hline Test Statistic & & .131 \\
\hline Asymp. Sig. (2-tailed) ${ }^{\circ}$ & & $<.001$ \\
\hline
\end{tabular}

Source: Processed data with SPSS

\section{Figure 1: Kolmogorov-Smirnov Test Result}

With the significance value: $\alpha=5 \%$, and the total number $(\mathrm{n})=312$, the value of the Kolmogorov-Smirnov from the table are 0.076887272 . The result of the normality test of the variables using the Kolmogorov-Smirnov Test is that the absolute score is 0,131. Therefore, the data are categorized that the maximum value of $\mid$ FT - FS $\mid>$ value of Kolmogorov-Smirnov table, consequently, $\mathrm{H} 0$ is rejected and $\mathrm{H} 1$ is accepted. The result is hence indicating that the data is not normally distributed, thus the Mann Whitney $U$ test are required to be used to analyse the correlation of the efficiency before and during COVID-19 pandemic.

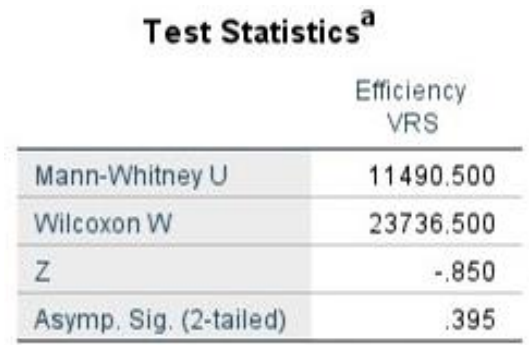

Source: Processed data with SPSS

Figure 2: Mann Whitney U Test Result

Based on Figure 2, The result of the Mann-Whitney $U$ test is that the significance value or Asymptotic Significance (2-tailed) is 0,395 which are categorized to be $>0,05$. Accordingly, the $\mathrm{H} 1$ is rejected and $\mathrm{H} 0$ is accepted. This result indicates that based on the statistical test using Mann-Whitney U test, the efficiency score before and during COVID-19 pandemic has no significant difference. 
As seen on Figure 3 below, the efficiency of the Islamic banks in during COVID-19 pandemic period is higher than before COVID-19 pandemic period, however in the 11th and 12th month, the efficiency during COVID-19 pandemic period is below the efficiency of the period of before COVID-19 pandemic. However, the efficiency during COVID-19 pandemic period is lower than before COVID-19 period because in the 11th and 12th month, the average of the second output variables which is the Operational Income, are relatively remaining the same in before and during COVID-19 pandemic, while both of the input variables which is Third Party Funds and Total Assets, are having a significant increase from before to during COVID-19 pandemic, which lead to the decrease in the efficiency score.

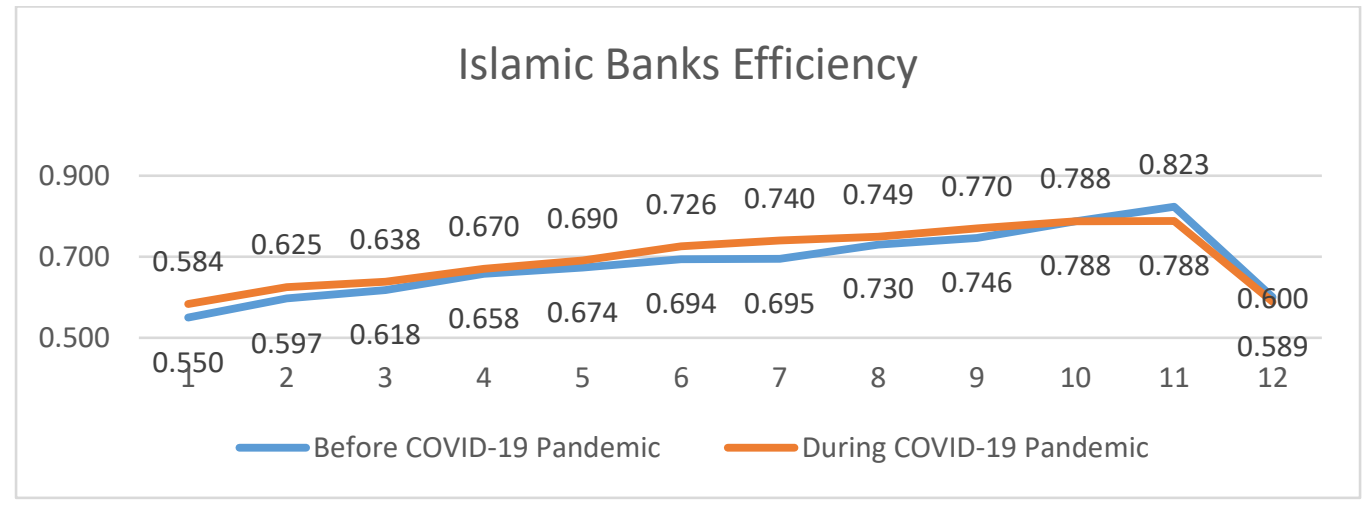

Source: Processed data with SPSS

Figure 3: Mann Whitney U Test Result

Moreover, based on the Mann Whitney U test in Figure 2, the results are that both of the group of the efficiency in before and during COVID-19 pandemic period are having no significant difference. This illustrates that even though in each banks efficiency score are varying to have an increase or decrease, but in the aggregate of 13 Islamic Banks in Indonesia, the occurrence of COVID-19 pandemic didn't affect the Islamic Banking in Indonesia, particularly in their efficiency. This means that the Islamic Banking in overall, could maintain their operation well, which resulted that there is no significant difference of the growth of Islamic banks especially in their efficiency although most of the economic activities and some financial sector in Indonesia was affected by COVID-19 pandemic and lead to the degradation.

\section{Conclusions}

The result of the analysis of the Islamic banking efficiency in Indonesia using the Data Envelopment Analysis (DEA) with Variable Return to Scale (VRS) model, shows that the Islamic banking in Indonesia has not yet been efficient since none of the efficiency score are equal to 1 over the period. However, the efficiency score tends to increase over the months and indicates that the efficiency score in during COVID-19 pandemic are relatively growing. And from the difference test resulted that there is no significant difference of the efficiency between before and during COVID-19 pandemic, which indicates that the growth of the Islamic Banking in Indonesia, particularly in the efficiency, is not significantly affected by COVID-19 pandemic.

However, this research is limited to only analyze the efficiency score of the Islamic banking by using the Data Envelopment Analysis (DEA) with Variable Return to Scale (VRS) model. Future research can extend the analysis by using the different model and different efficiency method. Moreover, this research is using an output orientation and intermediation approach, the research could also be extended by using a different orientation and approach to generate 
Volume 3 Issue 9 (September 2021) PP. 277-287 DOI 10.35631/AIJBES.39019

the variable used which is input orientation and asset approach or production approach in order to generate a more comprehensive result of the efficiency of the Islamic banking in Indonesia. And in addition, further research could perform an in-depth analysis of the reason of the increase/decrease of Islamic bank efficiency before and during COVID-19 pandemic.

\section{References}

Arifin, Danung (2020, March). Retrieved froom Badan Nasional Penanggulangan Bencana: https://bnpb.go.id/berita/status-keadaan-tertentu-darurat-bencana-wabah-penyakitakibat-virus-corona-di-indonesia-

Ascarya, \& Yumanita, D. (2005). Gambaran Umum Bank Syariah (Issue 14). Pusat Pendidikan dan Studi Kebanksentralan (PPSK). Jakarta.

Hidayat, Rahmat. (2014). Efisiensi Perbankan Syariah Teori dan Praktik. Gramata Publishing. Bekasi.

Indonesia Financial Services Authority (OJK). (2019). Indonesia Banking Booklet 2019 (Edition 07). Indonesia Financial Services Authority (OJK). Jakarta. https://www.ojk.go.id/en/kanal/perbankan/data-dan-statistik/booklet-perbankanindonesia/Pages/Indonesia-Banking-Booklet-2019.aspx

Indonesia Financial Services Authority (OJK). (2019). Statistik Perbankan Syariah. Indonesia Financial Services Authority (OJK).

Indonesia Financial Services Authority (OJK). (2020). The Indonesian Financial Services Sector Master Plan 2021-2025. Indonesia Finansial Services Authority (OJK). https://doi.org/10.36535/0548-0019-2020-12-3

Indrawati, Y. (2009). Analisis Efisiensi Bank Umum di Indonesia Periode 2004-2007; Aplikasi Metode Data Envelopment Analysis (DEA).

Islamic Financial Services Board. (2020). Islamic Financial Services Industry Stability Report 2020. In Islamic Financial Services Board.

Muharam, H., \& Pusvitasari, R. (2007). Analisis Perbandingan Efisiensi Bank Syariah di Indonesia dengan Metode Data Envelopment Analysis (periode Tahun 2005). Jurnal Ekonomi Dan Bisnis Islam, 2(3).

Nugroho, L., Utami, W., \& Meiwanto Doktoralina, C. (2020). Covid-19 and the Potency of Disruption on the Islamic Banking Performance (Indonesia Cases). International Journal of Economic and Business Applied, 1(1). http://ijeba.makarioz.org/

Nuryadi, Astuti, T. D., Utami, E. S., \& Budiantara, M. (2017). Dasar-dasar Statistik Penelitian. Sibuku Media. Yogyakarta.

Rakhmadi, R. S. (2010). Analisis Efisiensi Dan Produktivitas Perbankan.

Riani, D., \& Hendrawan, S. (2020). Data Envelopment Analysis (DEA); Perbandingan Efisiensi Bank Syariah Dan Bank Konvensional Periode 2014-2018. Neraca Keuangan Jurnal Ilmiah Akuntansi Dan Keuangan, 15(2).

Silkman, Richard H. (1986). Measuring Efficiency: An Assessment of Data Envelopment Analysis. Jossey-Bass. San Fransisco.

Sugiharto, T., Azimkulovich, E. S., \& Misdiyono. (2021). Impact Of The Covid-19 Pandemic On The Financial Performance Of Sharia Commercial Banks: An Empirical Evidence From Indonesia. Ikonomika, 6(1).

Sukur, M. H., Kurniadi, B., Haris, \& Faradillahisari, R. (2020). Penanganan Pelayanan Kesehatan Di Masa Pandemi Covid-19 Dalam Perspektif Hukum Kesehatan. Journal Inicio Legis, 1(1).

Sunarsih. (2017). Analisis Perbandingan Tingkat Efisiensi Perbankan Syari'ah dan Konvensional di Indonesia. Asy-Syirah Jurnal Ilmu Syari'ah Dan Hukum, 51(1). 